\title{
REPRESENTATION OF IDEOLOGY IN TEMPO NEWSPAPER ANCOL RECLAMATION NEWS DISCOURSE (Van Dijk Model Criticaldiscourse Analysis Study)
}

\author{
Arianty Visiaty \\ Universitas Negeri Jakarta, Jakarta, Indonesia \\ ariantyvisiaty_9906919013@unj.ac.id \\ Yumna Rasyid \\ Universitas Negeri Jakarta, Jakarta, Indonesia \\ yumna.rasyid@unj.ac.id \\ Miftahulkhairah Anwar \\ Universitas Negeri Jakarta, Jakarta, Indonesia \\ miftahulkhairah@unj.ac.id
}

Accepted: 2020-10-23, Approved: 2021-01-08 , Published: 2020-01-18

\begin{abstract}
The study aims to examine the ideological representations that appear in the news in the media. The analysis of this research uses the CDA Van Dijk concept. The data of this research is the news entitled "DKI Mengklaim Perluasan Ancol untuk Publik" published in TEMPO Newspaper, Monday July 6, 2020. From the analysis, this news shows support for the reclamation policy of the Ancol area of the DKI Jakarta Government. Besides, it is known that this news represents the ideological strategy of capitalism.
\end{abstract}

Keywords: Critical Discourse Analysis; Van Dijk model; ideology

\section{INTRODUCTION}

Ancol reclamation is a discourse that has emerged before the reign of Governor Anies Baswedan in DKI Jakarta. This problem from the start has raised pros and cons. This problem has been sticking out again since the issuance of Governor Decree No 237/2020 concerning the Permit for the Expansion of the Fantasy World Recreation Area (DUFAN) $\pm 35 \mathrm{Ha}$ and the Taman Impian Jaya Ancol Recreation Area covering an area of \pm $120 \mathrm{Ha}$. At the same time, there was news about this reclamation policy in the media. The media are the most effective means of conveying ideology.
Especially with the current development of ICT, news conveyed through the mass media is rapidly spread widely to the public.

The mass media, mostly newspapers play a role in telling events, mainly in constructing various realities that will be reported in the form of stories or meaningful discourses (Badara, 2014). In reporting about the reclamation of the Ancol area, the mass media plays a role in telling the reality of events related to reclamation in the form of meaningful discourses. Language is the main element in conveying. However, the function of language does not only convey reality, but also 
determine the image (the image meaning) about a media reality that appears in the minds of the public (Badara, 2014).

According to Sujiman in Badara (2014), there are three things that can be done when carrying out construction leading to image formation, namely:
1. Symbol selection (language function)

2. Selection of facts to study (framing strategy)

3. Willingness to give place (agenda setting)

First is the selection of symbols. The choice of symbols will affect the meaning that appears. According to the semiotic theory, a text in news is a collection of signs, starting from words, phrases, numbers, photos, pictures, and even the news packaging. Second, framing is a construction of reality which results in discourse. The frames' arrangement is based on various internal and external media interests, whether technical, economic, political, or ideological. Third, create space and time for reporting (agenda-setting function) (Badara, 2014). Kraus and David in Badara (2014), say that the media's function is to form the meaning and interpretation of mass media towards events radically, and can change people's interpretations of the reality and patterns of their actions.

Based on the explanation above, it can be said that the mass media contains symbols that are packaged in framing in the form of discourse, which including the interest of various parties with specific objectives. The meaning contained in the discourse in the form of news can change people's interpretation, in this case the reader, of a reality, and can even change their patterns of action.

Every language used in the news implies the ideology of the parties involved in the media institution. It could be the ideology of the editorial board, journalists, or the owner of the media's institution's capital. Media is a competition for various interests, and the competition between ideologies, especially the rulers' ideology to become more dominant in society. Sari, Putri, Herdi, \& Hamuddin (2018)'s research results shown that mass media act a momentous role in the production of beliefs, prejudice, and power on social context. Based on this, news readers must read critically not to be led by opinions that are usually related to power. Ideology is a central concept in analyzing critical discourse (Eriyanto, 2006). According to (Putra \& Triyono, 2018), through Critical Discourse Analysis people will know not only how the content of the news is displayed, but how and why the message is presented as well. In other words CDA can uncover the ideology that is in the text of a news.

The purpose of this research is to find an ideological representation that appears in the news "DKI Mengklaim Perluasan Ancol untuk Publik" published in TEMPO Newspaper, Monday, July 6, 2020.

The benefit of this research is to add insight into the study of ideological analysis in the media. To deepen knowledge about the method of assessing critical discourse analysis with Van Djik's analysis model.

\section{Critical Discourse Analysis (CDA)}

Discourse is a form of communicative actions which include communication structure and communication intended use (Widiastuti, 2020). Analysis of discourse is a way to study communicative actions by looking at what and how people communicate (Widiastuti, 2020). Critical discourse analysis is an analysis of language in its use by using a critical paradigm. Critical discourse analysis is 
an attempt to reveal the subject's hidden intentions (writer) who put forward a statement (Aliah, 2014). CDA explores the relationship between language users in terms of news being readers and unequal power relations (Kristina, Ardi, Shera, \& Purnomo, 2020). The term critical in CDA shows and describes the hidden relationship between language, power, and ideology (Kristina et al., 2020). More over, CDA is a powerful tool in deconstructing texts to probe the intended ideological representations (Ramanathan \& Hoon, 2015). From this, it can be said that CDA is an analysis of a discourse that uses a critical paradigm to see hidden intentions related to power and ideology.

The objectives of CDA, according to Haryatmoko (2019), are:

1. Analyzing discourse practices that reflect or construct social problems.

2. Researching how ideology is frozen in language and finding ways to dissolve ideologies that bind language or words.

3. Raising awareness to be sensitive to injustice.

4. Help provide solutions to barriers that hinder social change.

Meanwhile, the ultimate goal of CDA is for social and political change (Haryatmoko, 2019). Several main figures present the CDA analytical approach, among them are Normal Fairclough with the dialectical relational approach (DRA), Teun A. Dijk with the Socio Cognitive Approach (SCA), Ruth Wodak with the discourse-historical approaches (DHA), and Sara Mills with feminist stylistics approach (FSA).

\section{Van Dijk's Critical Discourse Analysis Approach}

The approach proposed by Van Dijk in the CDA study is called the socio-cognitive / social cognition approach. Social cognition in discourse includes a triangular relationship between discourse-cognitive-society (society). Another approach to the CDA study mostly relates discourse to the community. The socio-cognitive approach emphasizes that the relationship between discourse and society is cognitively mediated. Discourse structure and social structure are two different things and can only be related to the mental representation of language users as individuals and part of society. Mental structures or cognitions that can connect social discourse include knowledge, attitudes, and ideology(DIJK, 2009) .

Van Dijk's discourse analysis model has three dimensions, namely text, social cognition, and social context. In the text, what is examined is how the text structure and discourse strategy are used to present a particular theme. Social cognition studies the text production process that involves individual cognition based on their profession. Based on this, readers can make presuppositions regarding the content, themes, topics of discussion, and ways of presenting each individual with various professions' backgrounds. The social context criticizes the construction (construction) of discourse in the community regarding a particular problem/topic. This model can be described as follows (Kristina et al., 2020). 
Critical Discourse Analysis

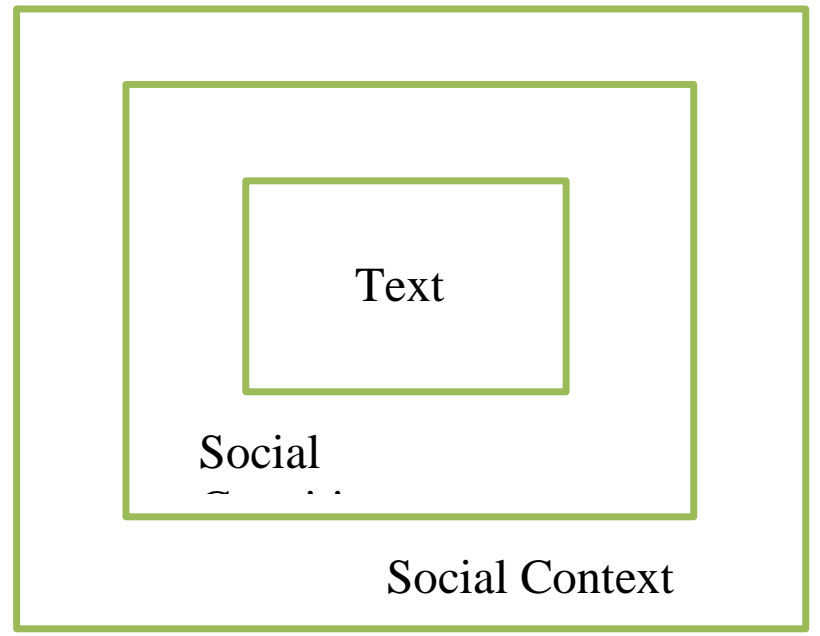

Figure 1. Van Dijk Analysis Model (Aliah, 2014)

Further, Van Dijk divides the discourse structure into three parts, namely:

1. Macro Structure

It shows the overall meaning, or global meaning that can be seen from the topics and themes of discourse raised by a text. Or also called thematic elements

2. Superstructure

It is a text outline or schematic element. Usually includes an introduction, content, conclusion and conclusion.

3. Micro Structure

It is a local meaning of a text which can be seen from the syntactic, semantic, stylistic, and rhetorical elements.

Also, Van Djik's critical discourse analysis study includes a meso level consisting of social cognition analysis and social (context) analysis.

\section{METHOD}

This research is descriptive qualitative research that uses the critical discourse analysis approach from Teun A. van Dijk. The data in this study are news in the newspaper TEMPO published on July 6, 2020, with the title "DKI Mengklaim Perluasan Ancol untuk Publik" and was written by Inge Klara Safitri. Data analysis used qualitative data analysis procedures: 1) data reduction, 2) data presentation, 3) verification, or concluding.

\section{RESULTS AND DISCUSSION}

The research's results will be discussed in stages, starting with the results of microstructure analysis, superstructure (schematic), and macrostructural analysis (thematic). 


\section{A. Micro Structur}

At the microstructure level, the analysis is carried out in syntax, semantics, stylistics, and rhetoric.

\section{1) Details}

Discourse elements related to details are associated with controlling information conveyed by someone (Eriyanto, 2006) . In news discourse, news writers will over-write or display information under their interests or the ideology they wish to convey. In the news "DKI Mengklaim Perluasan Ancol untuk Publik," there are two general discourses that have developed regarding the issue of Ancol reclamation. The first issue that supports the reclamation policy, and the second issue, does not support the reclamation policy. Based on the analysis results, the authors elaborate more on the first issue than the second issue.

In the first issue, the author describes the benefits of reclamation in the form of the establishment of public facilities such as community recreation areas, children's playgrounds, the construction of the Prophet Muhammad SAW's historical museum, and the use of dredged land, and there will be no adverse impacts on the environment. The description of the positive effect of this reclamation is written in 3 paragraphs. Whereas those that do not support the reclamation policy, only one sentence is written related to the breach of campaign promises, and only one paragraph for permitting the area of reclamation land. "DKI Mengklaim Perluasan Ancol untuk Publik" the benefits of reclamation and an explanation of the absence of adverse impacts of reclamation are spelled out explicitly and clearly. However, the issues related to campaign promises are drawn implicitly.

\section{2) Intention}

The intent is closely related to detail, detailed discourse shows the intention of the news writer explicitly. The purpose of writing explicitly is so that people can only receive information that is desired and contains the author's interests. Meanwhile, information that will harm the writer is written implicitly to hide from uncritical readers. In the news of the issue of the campaign promise, it is written as follows, "Aktivis lingkungan menuding hal tersebut melanggar janji kampanye Anies untuk menghentikan reklamasi." This sentence implies a problem with the reclamation action, but it is not explained explicitly.

\section{3) Coherence}

Coherence is the relationship or relationship between words or sentences in the text (Eriyanto, 2006). Coherence can be observed through the conjunctions used in the text. The use of conjunctions in this news is mostly done to clarify support for the reclamation policy. These conjunctions are as follows:

\section{a) Sebab}

This conjunction is used in the sentence "Sekretaris Daerah Jakarta Saefullah menyatakan izin perluasan lahan Ancol dan Dufan dikeluarkan demi kepentingan publik. Sebab, hasil perluasan lahan itu akan digunakan untuk tempat rekreasi warga tempat bermain anak, dan pembangunan museum sejarah Nabi Muhammad SAW.". "Sebab" is a conjunction used to express cause and effect. The author of the above sentence wants to clarify the meaning of "kepentingan publik", by adding an explanation of the reason why reclamation is a public interest, using a 
statement of reason using the conjunction "sebab".

\section{b) Supaya}

The other conjunction used in the sentence is "supaya". This conjunction explains the purpose or intent of the action in a sentence. The sentence used the conjunction "supaya" is " Tanah kerukan itulah yang akan dimanfaatkan supaya tidak tercecer tak beraturan di pantai utara Jakarta dan menimbulkan masalah lingkungan," ujar Saefullah, akhir pekan lalu." The conjuction "supaya" in this sentence is used to explain the purpose utilization of dredged land from other projects, such as MRT projects, etc. Expansion of the sentence by using the conjunction "supaya" to clarify the benefits of reclamation, as the use of scattered dredged land.

\section{4) Conditional Coherence}

Among them, conditional coherence is indicated using clauses as explanations (Eriyanto, 2006). This clause is used by the writer to bring out his interests, by giving a bad or good impression through the explanation in the clause. In the news "DKI Mengklaim Perluasan Ancol untuk Publik", there is one sentence which shows the conditional coherence, that is, "Menurut dia Sekertaris daerah tidak menjawab soal alasan DKI memberi izin reklamasi yang luasnya setara dengan 1,5 kali luas Kawasan Monas tersebut.". In this sentence, the clause "luasnya setara dengan 1,5 kali luas Kawasan Monas tersebut" describes the problematic reclamation permit related to the area to be reclaimed. The conditional coherence here is more likely to appear to support issues that do not support reclamation.
However, when examined the next sentence will give a different meaning. In the next sentence, the author delivers a statement from Elisa Sutanudjaja, Managing Director of the Rujak Center for Urban Studies, who says that reclamation is not a problem. The statement is written in the sentence "masalah tidak akan muncul kalau izin diberikan semata pada 20 hektare lahan yang sudah terlanjur terbentuk di Ancol Timur." This sentence contains conditional coherence. The clause "sudah terlanjur terbentuk di Ancol Timur", further explains that the reclamation basically does not have a problem because it has already been implemented by the DKI regional government before Anies. This sentence, explained by clauses, implicitly shows support for the reclamation policy.

\section{5) Passive Sentence Forms}

The news "DKI Mengklaim Perluasan Ancol untuk Publik", uses some passive sentences in its texts. Those passive sentences are:

(1) “...perluasan lahan itu akan digunakan untuk tempat rekreasi warga..."

(2) "Tanah yang digunakan untuk menimbun laut..."

(3) "Tanah kerukan itulah yang akan dimanfaatkan..."

(4) "Berdasarkan surat yang dilansir pada Februari lalu..."

The sentence structure can be made active or passive, usually the point that is considered important is placed at the beginning of the sentence. In sentences (1) - (3) above, the DKI Jakarta Government or the manager of the Ancol 
Tourism Area, the agency that will carry out reclamation activities, is hidden by using a passive sentence. By using a passive sentence, the sentence seems to mean that the main character (DKI Jakarta Government or the manager of the Ancol Tourism Area) does not have an important role. Even though the DKI Jakarta Government or the manager of the Ancol Tourism Area will carry out the reclamation and take advantage of this. Meanwhile, in sentence (4), the writer also hides the character or agency that launched the reclamation-related letter. This form is used so that the main character is not important, and the reader focuses about the sentence. So that the main figures who have interests will not be questioned.

\section{6) Inductive Sentence Form}

The inductive form is a form of sentence writing in which the core of the sentence is written at the end after additional information. In this news there are two paragraphs that use an inductive form:

(5) "Tanah yang digunakan untuk menimbun laut pun, Saefullah melanjutkan, memanfaatkan sisa pengerukan lima waduk dan 13 sungai dalam program Jakarta Emergency Dredging Initiative yang berlangsung sejak 2009. Berdasarkan laporan dalam Proyek Darurat Penanggulangan Banjir Jakarta itu, total hasil pengerukan waduk dan sungai di Jakarta selama 11 tahun terakhir mencapai sekitar 3,4 juta meter kubik."

(6)"Saefullah mengklaim peluasan lahan untuk Dunia Fantasi dan Ancol Timur tak
JURNAL PENDIDIKAN BAHASA DAN SASTRA

akan mengancam pencarian nelayan. Ini pertama kalinya DKI memberikan pernyataan resmi sejak izin perluasan Ancol menjadi polemik pekan lalu."

The sentence in bold in the data (5) and (6) is the core of the sentence. In data (5), the core sentence is "Laporan dalam Proyek Darurat Penanggulangan Banjir Jakarta...". Sedangkan "tanah yang digunakan untuk menimbun laut..." is additional information. The point of the data paragraph (5) is that the dredging project of reservoirs and rivers for flood relief has resulted in landfilling. Then given additional information which means that the land from the scrapings of rivers and reservoirs will be used to fill the sea. Additional information regarding the use of this land also continues until the next paragraph " Tanah kerukan itulah yang akan dimanfaatkan...”.

The focus of the sentence in the data paragraph (6) is "Ini pertama kalinya DKI memberikan pernyataan...". Meanwhile, an additional explanation is that "Saefullah mengklaim peluasan lahan untuk Dunia Fantasi dan Ancol Timur tak akan mengancam pencarian nelayan." The focus of data paragraph 6 is that the DKI Government first issued an official statement which became a polemic. To avoid the re-emergence of the polemic, the governor's secretary stated that land expansion would not threaten the search for fishermen.

Writing inductively on paragraph data (5) and (6) is deliberately done by the author to highlight the part of what the reader wants to capture. In this case, the use of land from dredging reservoirs and rivers to prevent flooding (5) and land expansion will not threaten fishermen's search (6). In other words, this induction writing is to influence the readers to support the Ancol area's reclamation. 


\section{7) Lexicon}

The choice of words used in the news can show the direction of the news. In this news, the word "perluasan" is widely used instead of the word "reklamasi". The word "perluasan" is used six times, while "reklamasi" is used twice. The author prefers the word "perluasan" rather than "reklamasi" because, the word "reklamasi" already has a negative meaning related to the news about the "reklamasi" policy that was initiated in the previous DKI Jakarta government which caused polemics. To refine and eliminate the meaning of "adanya masalah" contained in the word "reklamasi", the word expansion is used. This sorting of words shows the alignments of the news that support Ancol's reclamation policy. The word "perluasan" is also used in news headlines which is an important part of accentuating the news content. Apart from the word "perluasan", the writer also uses another synonym for the word "reklamasi", namely the word "berekspansi". The choice of the word "berekspansi" rather than "mereklamasi" has the same reasons as the choice of the word "perluasan".

\section{8) Presupposition}

The presuppositions seen in this news are those shown in the following statement,

(7) "Saefullah mengklaim peluasan lahan untuk Dunia Fantasi dan Ancol Timur tak akan mengancam pencarian nelayan."

(8) "Menurut Saefullah, lokasi di tengah pesisir utara Jakarta itu tidak akan budi daya ikan."

(9) "Dia juga memastikan penumpukan lumpur hasil pengerukan sungai tersebut tidak berdampak buruk bagi lingkungan."

The clauses "...tak akan mengancam pencarian nelayan" (7), "...tidak akan bersinggungan dengan aktivitas penangkapan dan budi daya ikan" (8), dan "... tidak berdampak buruk bagi lingkungan"(9), is a presupposition where the truth is not yet known. This presumption supports the idea that reclamation activities are safe for the environment and will not affect marine fish habitats not to affect fishermen's income. This presumption was raised to influence the reader's opinion towards supporting Ancol's reclamation policy.

\section{9) Graphics}

Graphics serve to highlight what is considered important for the readers. The graphics to be discussed are graphics on news leads, photos, and photo captions in this news.

\section{News Lead}

The news lead uses a thick font and a larger font size than the news content; this is done to highlight important things that the writer wants to convey through this news. The news leads are as follows:

(10) "Salah satu peruntukan penggunaan lahan adalah museum sejarah Nabi Muhammad SAW."

The author's news lead in this news wants to highlight that one of the public interests that will be built in the location of the reclamation results is the historical museum of the Prophet Muhammad SAW. This statement was 
chosen by the author to seek sympathy for the majority religion's followers to agree to the reclamation because it is related to the interests of adherents of the majority religion as well. For this statement to stand out and easily catch the eye, the author writes this statement in the lead section, which is an important part of the news in the newspaper because it reflects the content and important things that want to be conveyed in thick font size and larger than the ones in the contents.

\section{Photos}

The news shows photos of several fishing boats perched on the beach in an area near the reclaimed location. The fishing boat in the photo looks some distance away, with the colors and appearance are not noticeably clear. Through this photo, the author wants to highlight that fishermen's condition has become one of the problems when reclamation is carried out. This photo is displayed because the author wants to illustrate that when the reclamation is carried out it will not have a destructive impact on fishers, and the situation after the reclamation will still have many fishing boats that can fish in calm conditions like in the photo

\section{Photo Information}

The information written below the photo is as follows:

(11) "Sejumlah kapal nelayan berada di dekat lokasi perluasan kawasan Ancol, Jakarta, Rabu lalu. “

The photo caption here is written in thick font and larger than the fond size in the news content to highlight the message to be conveyed through the photo caption. The photo description tells the contents of the photo that the author wants to highlight, namely, several fishing boats perched in one of the areas to be reclaimed in Ancol. The thing to be conveyed through the statement in the photo caption here is that the problem of reclamation, one of which is related to fishermen's livelihoods, will not affect fishermen's livelihoods. Fishers will be able to fish as usual, and the number of fishers will not decrease or disappear, as shown in the picture. As a clarification, the authors mention when this photo was taken (Wednesday) to emphasize the Ancol area's current condition, which will not change after reclamation. To emphasize that the reader reads the photo caption, the writer should write it in thick font and a font size larger than the font fond size in the news content.

\section{B. Super Structure}

The news title examined in this study is" DKI Mengklaim Perluasan Ancol untuk Publik", and

the lead is "Salah satu peruntukan penggunaan lahan adalah museum sejarah Nabi Muhammad SAW."

This news is preceded by a statement giving permission and the reason for issuing a license, namely for the people's benefit. To clarify the interests of the people in this introductory section are described examples of the people's interests in question, such as building a recreational place for residents, a place to play children, and the construction of a historical museum of the Prophet Muhammad SAW.

The news content section consists of two parts. The first part contains the problem of landfills. This section illustrates that the land used for stockpiling the Ancol area is unused due to scouring rivers and reservoirs for flood prevention projects, MRT, etc. so that it is not a problem for the environment.

Meanwhile, the second part of the news content is about the effect of the reclamation on fishermen's livelihoods and the environment. This section 
describes that reclamation will not affect fishermen's search because the location is different. It is explained that landfilling will not cause adverse effects on the environment around the reclamation area.

The closing section displays the opinion of Mrs. Elisa Sutanudjaja, Managing Director of the Rujak Center for Urban Studies, who feels dissatisfied with the governor's secretary's explanation. In this section, Elisa's opinion is described about the area of reclamation area that is too large, compared to what has been done in the previous DKI government.

If the introductory part and the content part are compared, the introductory part emphasizes the benefits of material reclamation, in the form of a place for recreation, play, and a museum. In contrast, the second part is more beneficial for the continuity of life. Placement of text about the material's benefits on the front because the material's benefits are more visible with the naked eye and feel real.

In the lead, the author highlighted one of the benefits said to be in the public interest, namely building a historical museum of the Prophet Muhammad. The appointment of the Prophet Muhammad SAW's historical museum's construction as the lead has a hidden message, in which the author wants to attract sympathy from followers of the majority religion to support Ancol reclamation because there are religious interests in it.

\section{Macro Structure}

There are two themes in the news "DKI Mengklaim Perluasan Ancol untuk Publik." The first theme is the DKI Jakarta government's claim that the expansion of the Ancol area is for the public interest. The DKI Jakarta government claims that reclamation is ultimately for the people's benefit, such as the construction of community recreation areas, children's playgrounds, and the construction of the Prophet Muhammad SAW's historical museum.

The second theme is the impact of reclamation. In the news, it is illustrated that the reclamation will not impact the environment because the land used is the result of the excavation of rivers and reservoirs for flood prevention projects, MRT, etc. As well, landfilling in the reclamation area will not affect the surrounding environment and will not affect fishermen's search.

The themes carried in this news text show their support for the DKI Jakarta government's reclamation policy.

\section{Social Cognition}

Tempo Newspaper is a newspaper that does not side with one side of the government, prominent businessmen, etc. The journalists of Tempo newspapers were given the freedom of journalists to follow their conscience in writing news, guaranteed by Tempo, following its principle of being a "watchdog." Tempo Newspaper does not demand neutrality from every journalist but instead emphasizes balance as an overall result in the newspaper (Keller, 2009) .

The news "DKI Mengklaim Perluasan Ancol untuk Publik" shows journalists' alignments where it is hard to support the reclamation policy. This is because the newspaper tempo does not demand its journalists' neutrality, so journalists are free to write the news they want to convey following the journalist's conscience. 


\section{E. Social Analysis}

The reclamation of the Ancol area has been a polemic since the days before Anies Baswedan's reign. The polemic was caused by differences of opinion between people's interests and environmental issues.

Anies Baswedan, in his 2017 election campaign for the governor of DKI Jakarta, expressed his disapproval of the reclamation project and promised to stop the reclamation when he was elected governor. The promise is as follows.

One of his promises is to stop the reclamation activities of Jakarta Bay. His statement is:

"Menghentikan Reklamasi Teluk Jakarta untuk kepentingan pemeliharaan lingkungan hidup serta perlindungan terhadap nelayan, masyarakat pesisir, dan segenap warga Jakarta.”

"Kita mengambil sikap bahwa reklamasi ini tidak setuju dan akan menjalankannya sesuai otoritas kita sebagai gubernur dan wakil gubernur. Ini penting. Harus ada sikap tegas. Realisasi setelah saya jadi gubernur," kata Anies."

(Source:https://news.detik.com/berita/d5077134/disindir-aktivis-begini-janjikampanye-anies-soal-hentikanreklamasi)

In 2018, after Anies became governor, he kept his promise and permanently halted the reclamation project and sealed several buildings on the reclamation site. However, through the Governor's Decree No. 237/2020, Anies has allowed the 155-hectare reclamation project to return through sea filling.
The reclamation permit, which the DKI Jakarta Government was reissued, is said to be in the public interest. This needs to be examined carefully, what is meant by the public, the extent to which the public benefits. Reclamation is a project undertaken by large investors. Reclamation projects require high costs to stockpile land. These investors will build buildings that will be sold and bought. They will make a big profit from selling the building. The construction of a recreation park and a museum will also provide enormous benefits for foreign investors. This system in which large capital owners can reap the most significant possible profit is a capitalist ideology.

This capitalist ideology is also implied in the news "DKI Mengklaim Perluasan Ancol untuk Publik." The owners of capital, who are the real figures who carry out the Ancol area's reclamation and development, are hidden by using passive sentences. It cannot be seen who the actual actors are and who will benefit.

In the news, it is described that the public will benefit from the construction of recreational parks and museums by highlighting the points in the news introduction. However, it needs to be observed whether the community can take advantage of this for free, or in the end, it will provide benefits for investors. The construction of recreational areas and museums is highlighted in the news because of its material benefits so that readers can feel it psychologically. Besides, the emphasis is on the construction of the Prophet Muhammad SAW History Museum, which is a strategy of capitalists or investors to attract the hearts of followers of the largest religions in Indonesia.

One part of society that will have a significant impact on reclamation is the fishermen. Reclamation will cause 
natural pollution and kill fish so that the search for fishermen will be reduced. Regarding the environment and fishermen's livelihoods, reporting using the presumption that natural destruction will not occur and will not threaten nature's search is not something that can be proven. This is also a capitalist strategy so that readers can be led by this opinion.Results should be clear and concise.

\section{CONCLUSION}

That the news supports the policy of the DKI Jakarta Government to

\section{BAHTERA}

\section{JURNAL PENDIDIKAN BAHASA DAN SASTRA}

execute reclamation is the conclusion from the critical discourse analysis of the newspaper news dated July 6, 2020, entitled "DKI Mengklaim Perluasan Ancol untuk Publik " using the micro structure, supra structure, and macro structure analysis.

Whereas in the meso structure, especially social analysis, it shows that there are elements of the ideology of capitalism implicit in the black text, where this news is a capitalist strategy. Or it can be said that this text represents a capitalist ideology because the parties that benefit the most from reclamation are big investors

\section{DKI Mengklaim Perluasan} Ancol untuk Publik

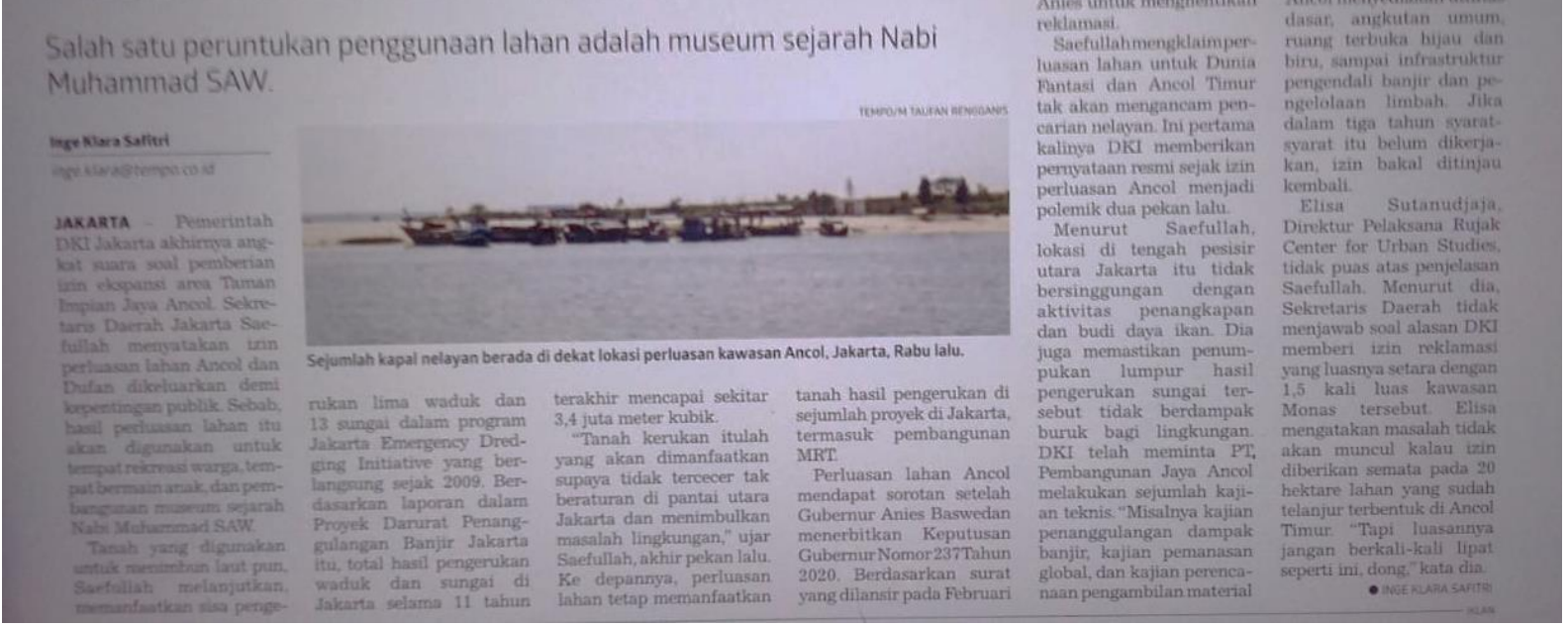

\section{REFERENCES}

Anwar, Miftahulkhairah et.al. 2020.

"Interpreting Impoliteness in Indonesian Languange: The Case of Short Story 'Sore."' Humanities \& Social Sciences Reviews 8 (1): 240-46

Badara, A. (2014). Analisis Wacana:
Teori, Metode, dan Penerapannya pada Wacana Media. Prenada Media.

DIJK, T. A. VAN. (2009). critical discourse studies: a sociocognitive approach In Methods for Critical Discourse Analysis. (R. Wodak \& M. Meyer, Eds.). SAGE.

Eriyanto. (2006). Analisis Wacana Pengantar Analisis Teks Media. 
LKiS Yogyakarta.

Haryatmoko. (2019). Critical Discourse Analysis (Analisis Wacana Kritis) Landasan Teori, Metodologi, dan Penerapan. Rajawali Pers.

Keller, A. (2009). Tantangan dari Dalam Jakarta, 2009 Otonomi Redaksi di 4 Media Cetak Nasional: Kompas, Koran Tempo, Media Indonesia, Republika. Dunia Printing Selaras.

Kristina, D., Ardi, H., Shera, M., \& Purnomo, S. F. L. A. (2020). Analisis Wacana Kritis. Pustaka belajar.

Putra, H. P., \& Triyono, S. (2018). Critical Discourse Analysis on Kompas.com News: Gerakan \#2019AntiPresiden. Leksema Jurnal Bahasa Dan Sastra, 3(2), 113-121.

Ramanathan, R., \& Hoon, T. A. N. B. E. E. (2015). Application of Critical Discourse Analysis in Media Discourse Studies. 3L: The Southeast Asian Journal of English Language Studies, 21(2), 57-68.

Sari, R., Putri, S. E., Herdi, \& Hamuddin, B. (2018). Bridging Critical Discourse Analysis in Media Discourse Studies. Indonesian EFL Journal, 4(2). https://doi.org/10.25134/ieflj.v4i2. 1379.Received

Widiastuti, N. P. S. (2020). A CRITICAL DISCOURSE ANALYSIS OF MOHAMAD NASIR'S SPEECH. BAHTERA: Jurnal Pendidikan Bahasa Dan Sastra, 19(2). https://news.detik.com/berita/d5077134/disindir-aktivis-beginijanji-kampanye-anies-soalhentikan-reklamasi 